\title{
Sartre's Theory of Character
}

\author{
Jonathan Webber
}

European Journal of Philosophy 14 (1): 94-116. 2006.

\begin{abstract}
:
Various ethical theories recommend developing a morally sound character, and therefore require an understanding of the nature and development of traits. Philosophers usually accept the Aristotelian view that traits are a combination of habit and insight. Sartre's early work offers an alternative: traits consist in projects. One aim of this paper is to show that this is indeed Sartre's view, by explaining the errors that have lead philosophers to ignore his theory of character or deny that he has one. The other is to clarify the theory, by investigating his notion of project and its relation to other prominent aspects of his philosophy, by distinguishing a broadly Sartrean theory of character from Sartre's own brand of this theory, and by comparing this broadly Sartrean theory with the Aristotelian theory. The paper focuses on Being and Nothingness and The Transcendence of the Ego, but also discusses some of Sartre's other works.
\end{abstract}

\section{Notice:}

This is an electronic version of an article published in European Journal of Philosophy: complete citation information for the final version of the paper, as published in the print edition of European Journal of Philosophy, is available on the Blackwell Synergy online delivery service, accessible via the journal's website at http: / / www.blackwellpublishing.com/journal.asp?ref=0966-8373 or via http: / / www.blackwell-synergy.com 


\title{
Sartre's Theory of Character
}

\author{
Jonathan Webber
}

Various influential ethical theories propose that we should strive to develop morally sound character traits, either because good actions are those that issue from good character traits, or because good traits are those that generally incline us toward actions that are good for some independent reason such as the intentions with which they are performed or the consequences of performing them. This proposal obviously raises questions about the nature and origins of character traits, and our degree of control over them. For if we cannot develop our traits then this proposal should be abandoned, and if we can then we need to know how this is best achieved.

One prominent strand running through Jean-Paul Sartre's extraordinary career is a concern with these interrelated issues. Though he rarely uses the terms 'personality', 'character', or 'trait', these notions are at the heart of his philosophical, political, biographical, and fictional writings. He first propounded a theory of the nature of character in one of his earliest publications, The Transcendence of the Ego, enlarged upon it in Being and Nothingness, and continued to alter and refine it until his death. It may seem odd, then, that while the current debate over the nature of character makes occasional reference to his idea that people are commonly in 'bad faith' about their own traits, it never draws on his theory of what these traits actually are.

The debate over character could therefore be enriched by drawing on Sartre's extensive work in this area and the distinctive perspectives it affords. But this requires considerable clarification of Sartre's theory, since misconceptions of it abound among commentators on his work and among philosophers in general. This paper aims to dispel those misconceptions, and to mark the basic outline of Sartre's view of character. The details of his theory evolved within this outline throughout his work. But the logical space it encloses is not replete with Sartre's own ideas: further positions can be formulated within the Sartrean outline, just as there can be Aristotelian theories other than Aristotle's. The debate about character could benefit from Sartre's work, therefore, both by investigating the development of his own ideas and the reasons for this development, and by pursuing independent lines of thought within the Sartrean framework. Both projects will be facilitated by the clarification of that framework.

This paper begins by showing that the question of the nature of character traits is the question of what plays a certain functional role in the production of our behaviour. Then the reasons why Sartre's answer to this question is generally ignored are explained, and dismissed as mistaken: section II discusses the

European Journal of Philosophy 14:1 ISSN 0966-8373 pp. 94-116 (C) 2006 The Author. Journal compilation (C) Blackwell Publishing Ltd. 2006, 9600 Garsington Road, Oxford OX4 2DQ, UK and 350 Main Street, Malden, MA 02148, USA. 
reasons why philosophers in general might assume that any Sartrean answer to the question will not be worth considering, and sections III and IV explain why commentators on Sartre's work either overlook his theory of character or deny that he has one. Having shown these views to be mistaken, section V outlines Sartre's theory, which is the view that character consists in projects. The notion of project employed in Sartre's work is clarified in section VI, and the idea of a broadly Sartrean theory of character as consisting in projects is explained and distinguished from Sartre's original version of this theory. The final section brings out the points of similarity and difference between this theory and the commonly held Aristotelian view that character traits consist in emotional and desiderative dispositions, and raises the possibility of combining the two accounts.

An individual's character is that person's collection of character traits, and these can be defined as relatively stable dispositions to think, feel, and behave in certain ways in certain situations. Two traditional examples are bravery and cowardice, the dispositions to think, feel, and behave in a brave or cowardly manner in the face of real or apparent danger. Other, more restricted examples might be being talkative at lunch or nervous at office parties. Exactly what is and what is not to count as a character trait, of course, depends on which account of the nature of character is to be accepted, and that is a matter of debate. But all sides agree that a trait must be relatively enduring: one cowardly act does not a coward make, as Aristotle observed, just as one swallow does not make a spring (NE: 1098a19). On the other hand, this does not mean that traits must be fixed: there is nothing contradictory in the idea of character-development.

The language used to characterise the patterns in a person's thoughts, feelings, and behaviour need not always refer to character traits, since some of it might refer to the absence of traits. An inconsiderate person, for example, might best be described as one who lacks the trait of consideration for others, one whose behaviour noticeably lacks such consideration, rather than one who has the trait of behaving inconsiderately (see Goldie 2004: 16). But even such negative trait terms reflect the close, dispositional relation between traits and behaviour patterns just as positive trait terms do: positive terms such as courage or sociability at office parties are named after the kinds of thoughts, feelings, and behaviour they dispose one towards; negative terms are named after the kinds of thoughts, feelings, and behaviour one is not disposed towards.

Positive trait terms, those that actually name relatively stable dispositions to think, feel, and behave in the ways they indicate, are therefore functional terms. For something to be a character trait is for it to play a certain functional role. So the question of what character traits consist in is, as John McDowell (1979: §2) has pointed out, the question of what kinds of mental state play that functional role. The Sartrean answer to this question is that one is disposed to think, feel, and behave in certain ways by the projects one has undertaken in response to one's

(C) The Author 2006. Journal compilation (C) Blackwell Publishing Ltd. 2006 
condition and environment. This is the broadly Sartrean idea to be explained in this paper. Before moving on to such explanation, however, it is necessary to clear away potential objections to the very idea that Sartre has anything valuable to contribute to the debate about character.

If Sartre has so much to offer the debate over character, then why are participants in that debate not already drawing on his work? There are a number of reasons why this might be so. These are also reasons why philosophers might actively resist the suggestion that his work ought to exert considerable influence over that debate. These reasons result from perceptions of the nature of Sartre's work that are widespread among contemporary theorists, but that we will see to be mistaken. These mistaken impressions are largely Sartre's own fault, since they are due in part to the difficulty of penetrating his complex idiosyncratic terminology, in part to the sheer scale of his philosophy and his tendency to present any aspect of it against the backdrop of much more of it, and in part to his exaggerations of the importance or range of some part of his theory when discussing that part. But mistaken they are, and part of the task of understanding Sartre's rightful position in the debate about character is seeing why they are mistaken.

One problem is that Sartre's presentation of his view of character in Being and Nothingness is interwoven with his complex ontology of being and nothingness, object and consciousness, being in-itself and being for-itself. This can easily give the impression that one cannot consider his theory of character without accepting a vast and abstruse metaphysical system to underpin it. This impression is mistaken, as I hope that this paper will demonstrate by presenting his theory of character without reference to that metaphysical system.

But there is a more specific form of this problem. Sartre's work might also give the impression that his theory of character is inextricable not from his metaphysics in general, but from his theory of 'radical' freedom and responsibility. Since many philosophers find Sartre's theory of freedom and responsibility either extremely obscure or simply unacceptable, this would provide a reason to ignore his work on character. In his early philosophy, Sartre denies all deterministic theories of human action, and so faces the problem that if action is undetermined, then it seems it must be random. Since we seem to find intelligible patterns in our own and each other's behaviour, it seems that action is not random. And since moral responsibility seems to require that people have control over their actions, it seems that agents cannot be responsible for actions that are random. Sartre therefore faces the conundrum of explaining how action can be neither determined nor random. Many philosophers think such an explanation cannot be given, and Sartre's own attempt to explain this is rarely considered as a candidate solution to the problem. ${ }^{1}$ It seems therefore that his theory of freedom is obscure and at the very least in need of further development. But the fact that Sartre later distanced himself from his early theory of freedom

(C) The Author 2006. Journal compilation (C) Blackwell Publishing Ltd. 2006 
and responsibility might be taken as evidence for something stronger: that whatever this obscure theory of freedom is, it is probably unacceptable anyway, since the person best placed to understand it ended up rejecting it. $^{2}$

However we should assess Sartre's early discussions of freedom and responsibility, the acceptability of his conception of character does not rely on them. In fact, his early and famous emphasis on 'the absolute character of the free commitment' as 'at the very heart and centre of existentialism' (EEH: 47) is disingenuous. His later philosophy preserves his existentialist approach to character even as it denies the earlier theory of freedom and responsibility that was built upon it, and that there is no contradiction involved in doing so will be made clear in the course of this paper.

A further reason to resist the idea that Sartre's philosophy has much to offer the current discussion of character might be due to his often-repeated claim that 'existence precedes essence', which he links to his theory of freedom and responsibility in his early works. This slogan expresses two related ideas: that individuals do not have natures or essences that determine their behaviour, and that there is no such thing as human nature or a human essence. A person 'first of all exists, surges up in the world-and defines himself afterwards' (EEH: 28; see also $B \mathcal{E} N$ : 490). This means, roughly, that the character trait terms that we use to describe ourselves and other people should not be understood to designate properties that determine behaviour in given situations. They are not analogous to terms designating heights and weights, which do pick out properties that determine the behaviour of physical objects in given situations. Individuals do not have properties such as honesty or dishonesty, courage or cowardice, that force them to behave this way or that in response to external stimuli, and there are no such properties generally applicable to all humans.

This aspect of existentialism can certainly look like the claim that there are no such things as character traits. Such a view might seem to be of interest to philosophers engaged in the debate over character traits, since by denying the terms of the debate entirely it might open up and recommend wholly new approaches to understanding ourselves and one another, and therefore to ethical and social theory. But such a denial faces a problem parallel to that faced by the denial of determinism. If there are no character traits, then what explains the apparent consistency of individual and human behaviour? Why isn't human behaviour just random? The very fact that we have developed the terminology of character traits indicates that we find consistent patterns in people's behaviour, which we would not find if their behaviour were random. The outright denial that there are any such things as character traits will be extremely implausible, precisely because such a denial will be left with the difficult task of explaining the origins of our folk psychological notion of character. ${ }^{3}$

Sartre's view is neither as simple nor as radical as the denial of character traits, however. As we will see, Sartre's early view is rather that character traits do not determine behaviour, and are within the agent's control. Character traits, on this view, ultimately result from the projects one has chosen to pursue in life, and since one can change these projects one can change one's character traits. One could not

(C) The Author 2006. Journal compilation (C) Blackwell Publishing Ltd. 2006 
choose to change one's projects, moreover, if they simply determined one's behaviour, since discarding one's projects itself involves behaviour contrary to the behaviour recommended by those projects. Clearly, this view is not the denial of character traits, but rather the view that the intelligible patterns in people's behaviour are a function of their inclinations to behave in one way rather than another, inclinations that they can resist and ultimately change.

The relation between such inclinations, projects, and character traits will become clearer in the following discussion. But it is worth noticing that the slogan 'existence precedes essence' claims only that character traits result from interactions with the environment, and are not fixed from birth: 'a coward ... is not like that on account of a cowardly heart or lungs or cerebrum' (EEH: 42-3). In his early work, Sartre claims that the character traits that result from interactions with the environment are freely chosen responses to one's situation: the coward 'is like that because he has made himself into a coward by his actions' (EEH: 43). Sartre's later rejection of this terminology of choice, freedom, and responsibility is based on increasing consideration of the social and economic pressures that lead people to respond to their conditions and environments in the ways that they do. He rejects his earlier terminology as an inappropriate description of the ways in which projects and hence character traits are adopted and revised, but not his theory of the relation between character traits and projects. ${ }^{4}$

Finally, one might want to resist the idea that Sartre's philosophy contains an interesting account of the nature of character traits on account of his discussions of 'bad faith' and 'the look' in Being and Nothingness and elsewhere. One might take Sartre's discussion of 'bad faith' to claim that we do not really have character traits, but pretend to ourselves that we do have them in order to blame them for our behaviour. One might similarly take Sartre's discussion of 'the look' as the basis of interpersonal relations to claim that we inevitably view other people as having character traits when in fact they do not have them. ${ }^{5}$ This of course involves reading Sartre as claiming that there are no such things as character traits, a view which we have seen to have little contribution to make to the debate about character. But even worse, it renders his position vulnerable to a charge of inconsistency: surely these dispositions to treat ourselves and others in certain ways count as character traits, and any such dispositions that are universal or inevitable count as traits of human nature.

Since this paper argues that Sartre has an interesting theory of character traits, however, it argues by implication that Sartre's theories of 'bad faith' and 'the look' cannot be about attributing character traits where there are none. Those theories must rather be concerned with the errors we make concerning the characters that people really do have. Such theories might still be of interest to debates over the epistemology of character. For someone who thinks that we do have character traits but that these are not as we usually understand them could find Sartre's diagnosis of our usual mistakes and of the motivations behind them a useful tool in explaining why we make the errors we make. Such debates are outside the scope of this paper, although Sartre's notions of bad faith and the look will be touched upon again in the course of it.

(C) The Author 2006. Journal compilation (1) Blackwell Publishing Ltd. 2006 
Although mistaken, these motivations for believing that Sartre has nothing to contribute to the debate over the nature of character are rooted in aspects of his philosophy that could have been expressed more clearly. They may well be informed, moreover, by the work of commentators on Sartre's philosophy, who tend not to discuss his view of character, and sometimes claim that he denied there was any such thing. This tendency might seem absurd when one considers the aims of his applied writings. His biography of Baudelaire, for example, aims to uncover the poet's personal characteristics that explain his writings and his bizarre lifestyle. The traits discussed include his avoidance of solitude, his seeking of moral condemnation and punishment, and his horror of and indeed contempt for all that is crudely natural and unsophisticated by human hand. Sartre ultimately traces these back to the aim of being unique (see $B$ : throughout). This account of what appear to be Baudelaire's character traits strongly suggests that Sartre had a theory of character at work here. Nonetheless, commentators on his philosophical writings do tend to overlook or deny his theory of character, so in order to provide a convincing account of his theory of character it is necessary to see why they do this and why they are mistaken.

\section{III}

There are two areas of Sartre's early thought that seem to lead commentators to neglect his theory of character, and even to leave no room in his philosophical anthropology for character traits at all. One is his account of the nature of the human way of being, being for-itself, as comprised of 'transcendence' and 'facticity'. The other is his theory that the self or ego is a 'transcendent' object. These two theories employ the term 'transcendence' in different senses. Although the errors made by commentators in discussing these theories do not result from confusing these two senses, it would be well to distinguish them here in order to clarify his views.

Both senses result from the basic meaning of 'transcendent' as 'going beyond'. In contrast to 'facticity', which denotes the given set of facts at any moment, 'transcendence' denotes the ability to go beyond the situation one finds oneself in. One can imagine things being otherwise, desire that they were otherwise, or pursue the goal of making them otherwise, and these are all ways of transcending or going beyond one's situation. When Sartre discusses the 'transcendence' of the ego, however, the term contrasts not with 'facticity' but with 'immanence'. It means that the ego is an object that is external to consciousness rather than contained within it, an object that we are aware of rather than an aspect of consciousness itself, and which has more to it than we are aware of at any given moment. Ordinary worldly objects like chairs and tables are also transcendent in this sense, as are certain non-physical objects like melodies and mathematical formulae. ${ }^{6}$

Commentators tend implicitly to take the claim that the human mode of being comprises transcendence and facticity to exclude any notion of character from

(C) The Author 2006. Journal compilation (C) Blackwell Publishing Ltd. 2006 
Sartrean anthropology, and tend implicitly or explicitly to take the claim that the ego is a transcendent object to mean that one's character or personality is merely imaginary. We will consider these two exegetical errors in turn, and see just why they are erroneous. Rather than simultaneously critique a range of commentators, a more straightforward strategy will be to critique one commentator whose work is paradigmatic of the erroneous approach to Sartrean anthropology common in the secondary literature, and to add references to other commentators where their reading of Sartre coincides with the paradigmatic case. Gregory McCulloch's book Using Sartre (1994) serves this role of paradigm very well, since it is fairly recent, very readable, and provides quite a detailed discussion of Sartre's understanding of human beings. McCulloch's book, moreover, is likely to be more influential than most among anglophone philosophers interested in character, not only because it is recent and readable, but also because it explicitly aims to discuss Sartre's work in the context of issues in recent anglophone philosophy of mind. But it should be borne in mind that McCulloch is by no means alone in reading Sartre this way.

The idea that the theory of transcendence and facticity leaves no room for character is partly rooted, for McCulloch at least, in equating 'transcendence' with 'freedom', and understanding 'the doctrine about freedom' as being 'opposed to the idea that we have a nature or essence which determines how we should act or live' (1994: 57). ${ }^{7}$ This latter claim is ambiguous between the denial that one's 'nature or essence' determines how one ought to behave, the denial that one's 'nature or essence' in fact determines one's behaviour, and the denial that we have a 'nature or essence' at all. The latter meaning is suggested, however, by the fact that McCulloch's definitions of facticity seem to exclude character traits. Facticity, according to McCulloch, comprises just 'the body, and its material history and environment' or 'our material surroundings, our own bodily form of existence, [and] our past decisions and choices that have brought us to where we are now' (1994: 4, 57). So for McCulloch's Sartre, a human being comprises just a material body and surroundings, a past, and the freedom to choose how to behave, none of which include or amount to character. ${ }^{8}$

There are comments in Being and Nothingness that suggest that Sartre considers our talk of character traits to refer not to present facts about a person, but to that person's past behaviour. 'Essence is what has been' might seem a clear assertion of this (BEN: 59,461, 472, 518). This phrase informs McCulloch's discussion, and so he describes Sartre's case of the guilt-ridden homosexual who denies his sexuality as a man denying that his past sexual behaviour fits a homosexual pattern, rather than as a man denying that he has a character trait of homosexuality (1994: 60). ${ }^{9}$ But Sartre's description of the essence of an individual as 'what has been' need not be understood in this way. In one place where Sartre uses the phrase, he goes on to say that:

Essence is everything in the human being that we can indicate by the words-that is. Due to this fact it is the totality of characteristics which explain the act. But the act is always beyond that essence; it is a human act

(C) The Author 2006. Journal compilation @ Blackwell Publishing Ltd. 2006 
only in so far as it surpasses every explanation which we can give of it, precisely because the very application of the formula 'that is' to man causes all that is designated, to have-been. (BEN: 59)

If essence is to explain an action, it seems that it could not be composed simply of past actions: there needs to be some explanation of how these past actions connect with the action to be explained. If essence is to be everything about a person that can be indicated by the words 'that is', moreover, it must include the body. It is not difficult to see how the body enters into the explanation of action, but it is difficult to see how it might be, at the time of action, something that 'has been' in the past. We should rather interpret this passage as claiming that a person's essence inclines them towards certain courses of action, but does not determine those courses of action. Action surpasses the inclinations that explain it. So describing a person in terms of body and character traits provides an explanation of that person's past behaviour, but not a definitive prediction of their future behaviour, since that person could always behave in ways contrary to their inclinations. The language of character, on this view, is not simply shorthand for patterns of past behaviour. It is genuinely explanatory of behaviour, but it is not fully predictive: it indicates only what one has been and done so far, not what one must continue to be and do.

This reading is supported by Sartre's subsequent discussion of what he terms 'psychological determinism', a view of human beings that 'provides us with a nature productive of our acts' and thereby 'denies that transcendence of human reality which makes it emerge in anguish beyond its own essence' (BEN: 64). In this passage, Sartre contrasts the notion of an essence with the deterministic notion of a nature. He objects not to the idea that humans have characters that explain their behaviour, or 'essences', but to the idea that they have characters that determine their behaviour, or 'natures' (see also BEN: 461-2, 465-6). As we have seen, McCulloch takes Sartre's terms 'nature' and 'essence' to be synonymous, which might help to explain why he excludes character from his account of Sartre's anthropology altogether.

Sartre's discussion of bad faith provides further support for the claim that his notion of facticity includes character traits that recommend rather than determine courses of action. His discussion hinges on his claim that any form of bad faith 'must affirm facticity as being transcendence and transcendence as being facticity' (BEN: 79). It must affirm that there is no more to one's ability to go beyond one's situation than is provided by one's facticity. Bad faith, that is, is the view that one's actions in a given situation are determined by one's facticity. This would require that one's facticity include one's character traits where these are understood as determining one's actions, as constituting a nature. The waiter can pretend to have the nature of a waiter, for example, only if this nature is understood as including the character traits that make him behave in the precise ways that he does, 'carrying his tray with the recklessness of a tightrope walker' and so on (see $B \mathcal{E} N$ : 82).

(c) The Author 2006. Journal compilation (c) Blackwell Publishing Ltd. 2006 
For Sartre, of course, this is a mistaken view of the relation between transcendence and facticity: one's ability to go beyond the situation one finds oneself in is not restricted to the abilities and inclinations embodied in one's facticity, but involves the freedom to behave in ways other than those recommended by one's character or essence. One's transcendence, that is, is not the same as one's facticity: it is limited but not determined by that facticity. A full discussion of the nature of bad faith is outside the scope of this paper, but it is worth noticing that Sartre considers his claim that one freely transcends one's situation to be a substantial point, not a pleonasm. Commentators who, like McCulloch, take Sartre's terms 'transcendence' and 'freedom' to be synonymous will thereby have trouble understanding his discussion of bad faith in Being and Nothingness.

A person's essence, for Sartre, includes character traits that incline that person towards certain types of behaviour but do not determine that behaviour. It is not simply restricted to a pattern of past behaviour, or to such a pattern plus bodily facts. Sartre's apparently contradictory definition of 'the human reality' as 'a being which is what it is not and which is not what it is' should be read in the light of this ( $B \mathcal{E} N$ : 81 ; see p. 90). The second part of the famous formula does not simply mean that a person cannot be wholly captured by a description of their past behaviour, or a description of their past behaviour and their current bodily and environmental condition, as commentators have usually claimed (see, for example, Catalano 1976: 84; Caws 1979: 86; Manser 1966: 61-2; McCulloch 1994: 56). It means rather that the total set of character traits that can truthfully be ascribed to an individual does not wholly capture that individual, since that person is free to behave in a way that is contrary to those character traits, even to the extent that the set of traits that can truthfully be ascribed now will need to be revised in the future. The first part of this formula refers, as we will see in section $\mathrm{V}$, to the place of continuing projects in the structure of character.

Given this wealth of evidence in favour of reading Sartre as holding that our facticity includes character traits that incline us towards but do not determine certain patterns of behaviour, it may seem odd that commentators have generally taken him to be claiming otherwise. The error is partly rooted, as we will see in the next section, in a misunderstanding of Sartre's discussion of the self or ego as a transcendent object.

\section{IV}

The idea that Sartre rejects any notion of character may seem justified by his discussion of the nature of the self in his early essay The Transcendence of the Ego. Sartre argues in this work that there is no such thing as a 'transcendental ego' or subject underlying or inhabiting consciousness. His basic strategy is to argue against the position Edmund Husserl held in his later, but not his earlier writings. This is the view that when we reflect on our own previous conscious episodes in the right way, we find a metaphysical subject or transcendental ego underlying or

(c) The Author 2006. Journal compilation (1) Blackwell Publishing Ltd. 2006 
inhabiting them. This subject is understood as a substantial entity that is not part of the public world, much like a Cartesian ego (see, for example, Husserl 1950: $\S$ 11).

Sartre opposes this view partly by arguing that Husserl is wrong to suggest that such an ego is required to unify consciousness, and partly by arguing that such an ego is incompatible with the nature of consciousness. But the lion's share of the book, and the most important for our purposes, is Sartre's argument that the only ego or self discovered in reflecting on our own conscious experiences is not 'transcendental', does not underlie or inhabit consciousness, but is rather 'transcendent', external to consciousness just as physical objects are. Sartre reaffirms this in Being and Nothingness, published seven years later, explicitly demurring only from the earlier claim that this point provides a solution to the problem of solipsism (BEN: 127, 259; see also: Morris 1985: esp. § 2; Richmond 2004).

McCulloch takes this to mean that, for Sartre, 'the self is a kind of construct only', and this seems to underlie his understanding of Sartrean anthropology as excluding character (1994: 7). Christina Howells similarly talks of 'the self as an imaginary construct and an unrealizable limit in The Transcendence of the Ego', and argues that for Sartre as for Jacques Lacan the self is 'a fictional synthesis' (1992: 327-30). Hazel Barnes agrees with this reading when she analyses the ways in which the ego is 'fabricated' by consciousness (1992: 27-36). But why should the claim that the ego or self is outside consciousness rather than within or underlying it be taken to mean that the ego or self is a fictional construct rather than a real object? After all, the physical world is outside of consciousness for Sartre, but he is not taken to hold that this depends for its existence on our awareness of it.

The answer to this is that there might seem to be an important disanalogy, in Sartre's system, between the kind of transcendent existence had by physical objects and the kind had by the ego. The sense that our surroundings have for us, the patterns of salience and significance we experience in the world, are a function of the ways in which we are aware of our surroundings, the ways in which we 'constitute' objects, as we will see in the next section. But the physical world nonetheless exists independently of consciousness: it has being in-itself. This is why, he claims, there is a 'resistance of things' or 'coefficient of adversity' in the world (BEN: 348), why the world 'does not depend on my whim' (BEN: 3). ${ }^{10}$ The ego, on the other hand, is more like a melody: just as we construct melodies from the sequences of notes that we hear, so we construct egos or selves from the sequences of actions and states that we observe in ourselves and others; just as a melody is not a being in-itself underlying the notes, he is often taken to say, the self or ego does not exist independently of our 'constitution' of it (see TE: 29-30).

Sartre's theory of the constitution of the ego is subtle, complex, and largely tangential to the present issue. But it is as mistaken to interpret Sartre as claiming that the self or ego does not really exist as it is to interpret him as saying that melodies do not really exist. Of course melodies exist! We encounter melodies in

(C) The Author 2006. Journal compilation (C) Blackwell Publishing Ltd. 2006 
the world, and we can study them. It is just that a melody is not a substantial object of which notes are properties or effects, but is itself a sequence of notes. The sounding of each successive note therefore cannot be explained by the existence of the melody, but only by the intentions of composer and player to produce that melody. Our access to melodies, however, is not through direct apprehension of those intentions, but through apprehension of the notes.

The analogy with melodies, therefore, need not be taken to express the idea that egos do not exist, but rather to express a theory of the kind of existence had by egos and of our epistemic access to them. After all, Sartre does claim that we encounter egos in the world and that psychologists study them; he does not call the validity of this branch of psychology into question, but rather makes a claim about which methods are proper to it (TE: 28, 45).

To say that an object is constituted, for Sartre, is not to say that it is unreal. If he did think these were equivalent, he could not draw the distinction between actions and states, on the one hand, and qualities, on the other, that he draws in The Transcendence of the Ego. His view here is that a self or ego is usually thought of as a totality of actions, states, and qualities, when in fact it is only a totality of actions and states. Qualities do not really exist, but actions and states do. He considers all three to be constituted nonetheless, just as the ego is constituted. The state of hating a particular person, for example, is manifested in a variety of thoughts, feelings, and actions, but is not wholly contained in any of them; it is given, in and by each movement of disgust, revulsion, and anger, but at the same time it is not any of them, it goes beyond them and affirms its permanence' (TE: 22). Hatred is real, but composed of rather than causing the events of disgust, revulsion, and anger that manifest it (see TE: 21-6). Similarly, 'action requires time in which to be carried out' and involves a sequence of mental and physical events (TE: 26). The action itself is a transcendent object, constituted from these various events (see TE: 26-7). Just as a melody is not a substantial object causing the notes that compose it, so an action is not a substantial object causing the events that compose it. But this does not mean that there are not really any actions.

Sartre describes qualities as 'optional unities of states' (TE: 27). By this he means that we tend to think of ourselves and others as having qualities that unify and explain our states, but that we need not think in this way. Indeed, in The Transcendence of the Ego, he thinks that this way of thinking is mistaken. To think of hatred for different people or deep-rooted rancour or long-lasting anger as indicative of being a hateful, rancorous, or angry person, to constitute such qualities as the sources from which the states and actions emanate, is to add something to the self or ego that it does not really contain; 'states and actions can find directly in the Ego the unity that they require' (TE: 28; see also pp. 28-41).

In calling the ego a constituted transcendent object, and in comparing it to a melody, therefore, Sartre is not claiming that it does not really exist, or that it is imaginary. His view is rather that it is a real part of the world, like actions and states, and can be studied scientifically, though our access to this ego is only

(C) The Author 2006. Journal compilation (1) Blackwell Publishing Ltd. 2006 
through surmise on the basis of actions and states, which can be apprehended more directly (see also TE: 15-6, 31).

This might make it seem even clearer that there is no place for character in Sartre's anthropology. For the set of qualities includes 'failings, virtues, tastes, talents, tendencies, instincts, etc.' (TE: 28), and so seems to include character traits. In the inventory of the ego given in Being and Nothingness, moreover, Sartre describes one's set of qualities as the ensemble of virtues, latent traits, potentialities which constitute our character and our habits' (BEN: 185); a quality is defined as 'an innate or acquired disposition' (BEN: 185).

There is, however, a subtle shift between the theory of The Transcendence of the Ego and that of Being and Nothingness, one that Sartre does not note in the later work. Where the earlier text draws a distinction between the reality of actions and states and the non-reality of qualities, the later makes no such distinction: the three are treated as equally real throughout the relevant passage (BEN: 184-90; see esp. pp. 186-7). This shift can be explained by the fact that the earlier theory does not explain why we can find intelligible patterns in people's behaviour, or why these patterns seem to differ from person to person. These intelligible patterns in a person's actions over time and in their states over time seem to require the presence of longer-term aspects of the ego, and these are qualities. ${ }^{11}$

The earlier opposition to the existence of qualities does not disappear altogether: as we have seen, Sartre remains opposed to the idea that such qualities determine behaviour, holding instead that they incline us towards certain types of behaviour. Perhaps the earlier work was motivated partly by the error of assuming that character traits can only be deterministic, and so taking the rejection of character to be part of the rejection of psychological determinism. If so, Sartre's revision of the theory of the ego in Being and Nothingness is not only a response to the need to explain the intelligibility of a person's behaviour and states over time, but is also motivated by the realisation that character traits need not be deterministic. In the terms distinguished in section III, the development of Sartre's thought from The Transcendence of the Ego to Being and Nothingness involved the realisation that people might have essences that explain their behaviour without having natures that determine it.

\section{V}

By the time of writing Being and Nothingness, therefore, Sartre had formulated the view that character traits, or 'qualities', are dispositions that incline one towards certain types of actions, but which cannot determine one's behaviour. This distinction between inclination and determination, between 'essence' and 'nature', is central to Sartre's theory of freedom. But this is not at the very heart of his theory, for he also has a distinctive and intriguing theory of what character traits or qualities consist in, a theory that one can hold independently of the theory of freedom. This theory is an account of what it is that occupies the

(C) The Author 2006. Journal compilation (C) Blackwell Publishing Ltd. 2006 
functional roles picked out by the terms 'character' and 'character trait', an account of what behavioural inclinations really are.

To approach this theory, it is necessary to understand how Sartre identifies the functional roles that character traits fulfil, or the overall functional role that character as a whole fulfils. It is necessary, that is, to investigate his account of the motivation of behaviour. Sartre couches this theory in terms of the relation between an action's mobile and its motif. The former term denotes a fact about the agent that can be cited in the immediate explanation of the action, whereas the latter denotes a fact about that agent's environment that can be cited in the same kind of explanation. To explain why I tidied the room, for example, you might explain it in terms of a motif such as the room being untidy or at least looking so to me, or you might explain it in terms of a mobile such as my wanting the room to be tidier. The motif is 'the reason for the act' and 'the ensemble of rational considerations which justify it', whereas the mobile is 'the ensemble of the desires, emotions, and passions which urge me to accomplish a certain act' (BEN: 467-8). ${ }^{12}$

Sartre's claim is that any reason motivating an agent can be described in either of two ways: 'motif and mobile are correlative ... the mobile is nothing other than the apprehension of the motif' (BEN: 471); the mobile is 'consciousness of [the] motif or, if you prefer, the apprehension of the situation as articulated in this or that way' (BEN: 492). My awareness of the room is filtered by my desire that it be tidy, which is why it looks untidy to me; my desire that the room be tidier is revealed to me by the room looking untidy. The idea is neither that one sort of explanation of my motivation is incomplete without reference to the other, nor that one sort is true where the other is false, but rather that explanations in terms of motif and those in terms of mobile simply pick out the same explanatory token event in different ways.

An individual action can therefore be explained in terms of motif or mobile, and both explanations reflect the agent's aims at the time. The world is constituted through the pursuit of aims: 'this projection of myself toward an original possibility... causes the existence of values, appeals, expectations, and in general a world' (BEN: 63). Sartre uses the term 'world' to denote not the mindindependent stuff that our bodies and surroundings are made of, but that stuff as it is organised into the complex of instruments, obstacles, and positively and negatively valued objects and events that we encounter. The organisation reflects our own aims. His key term 'situation' is intended to capture this idea that the way one's surroundings seem to one is a result of one's aims. He introduces the term when discussing the example of looking through a keyhole, when 'there is a spectacle to be seen behind the door only because I am jealous, but my jealousy is nothing except the simple objective fact that there is a sight to be seen behind the door' (BEN: 283). ${ }^{13}$ My situation, then, is the motif that explains my action: it is the appearance of my surroundings as organized in a certain way, inviting certain behaviour to achieve my aim. This aim need not be pursued; the invitation can be declined (see $B \mathcal{E N}$ : 54-8, 486). 'It is thus that the man who is angry sees on the face of his opponent the objective quality of asking for a punch on the nose' (BEN: 186).

(C) The Author 2006. Journal compilation @ Blackwell Publishing Ltd. 2006 
These aims are not themselves enough to play the role of character traits. Such aims can explain our behaviour in a given situation, but one swallow does not make a spring: a character trait explains the patterns in an individual's behaviour over a significant stretch of time. What a character trait explains in Sartre's system, therefore, is why one has certain aims when one does, why certain surroundings elicit certain types of mobile, and hence are organised into certain types of motif or situation. Such longer-term functional roles, for Sartre, are occupied by one's longer-term projects: 'it is the ensemble of my projects which turns back in order to confer upon the mobile its structure as a mobile' (BEN: 459). The aims I have at any given moment are to be explained by the projects I am engaged in pursuing, and so the patterns in my thoughts, feelings, and behaviour are ultimately to be explained with reference to these projects. Such projects can be very simple: in the passage just cited, Sartre explains someone's acceptance of low pay by reference to their project of staying alive.

Sartre is well aware that his theory of the explanation of behaviour implies that character is a matter of projects:

we find no given in human reality in the sense that temperament, character, passions, principles of reason would be acquired or innate data existing in the manner of things. The empirical consideration of the human being shows him as an organized unity of conduct patterns. $(B \mathcal{E} N: 498)^{14}$

This explains the first part of Sartre's seemingly contradictory definition of 'the human reality' as 'a being which is what it is not and which is not what it is'. The second part, as we saw in section III, is the claim that one is not identical with one's set of character traits, that one's behaviour is not determined by one's essence. The first, we can now see, is the idea that one's character is ultimately to be defined in terms of projects, and these refer to future possibilities that one is aiming to actualise and which are therefore not yet actual: your character is defined partly in terms of what you are not yet, the person who has achieved your current projects; or, in Sartre's terms, 'motifs and mobiles have meaning only inside a projected ensemble which is precisely an ensemble of non-existents' (BEN: 459).

Sartre's famous formula 'existence precedes essence' should also be understood in this way, though with the addition of the theory of freedom. One's essence depends on the projects one has chosen to pursue, but one could only make such a choice once one already existed. Such projects are nonetheless chosen, which means that they are not genetically determined and so not simply part of one's existence.

There are, of course, many issues involved in this idea that one's thoughts, feelings, and actions are to be explained by reference to projects that one has chosen. Not least among these is the fact that choosing itself seems to be an action, usually involving thoughts and feelings, and so the explanation might seem circular. This objection is easily obviated by distinguishing, as Sartre does,

(C) The Author 2006. Journal compilation (C) Blackwell Publishing Ltd. 2006 
two kinds of choice. One kind results from the various considerations being assigned relative weights, where the weights assigned depend on one's projects. This kind of choice involves thoughts and feelings. The other kind does not involve rational consideration, and the choice of a project can be of this sort (BEN: 472-3; 492-3). Whether the latter kind of 'choice' really deserves that name, however, and whether one can be held responsible for them, as Sartre seems to hold in his early work, are further questions.

Even if these questions are to be answered negatively, one's character might consist in one's projects nonetheless. Sartre's theory of what character consists in does not imply his theory of the acquisition of projects, or indeed any such theory. But this theory of the nature of character will remain obscure without further clarification of the notion of project at work in Sartre's philosophy. In order to bring the Sartrean theory into sharper focus, therefore, some investigation of his conception of project is required.

\section{VI}

Sartre's conception of a project is relatively under-explored by commentators, which might give the impression that he is simply employing our ordinary, everyday notion. There are, however, at least two important differences. One of these concerns the goal-directed nature of projects: although a Sartrean project always has a purpose, it need not have an objective; a project need not aim to bring about some specific change in oneself or in the world.

Writing a book, for example, is a project that does have an objective: the completion and publication of the book. A good example of a Sartrean project with no objective is the project that he considers to underlie anti-Semitism and all forms of racial hatred. This is the project of denying the three cardinal structures of the human condition: that we must earn our keep and our place in the world, that we must choose what to value as good and bad, and that we are responsible for our own actions. Anti-Semites, according to Sartre, see the first of these as resulting from being dispossessed of their birthright by a Jewish conspiracy rather than as a fact about being human, consider the birthright an objective good and the dispossession an objective evil, and consider this attitude to have been forced upon them by the intolerable circumstances in which they find themselves. The project underlying anti-Semitism and racial hatred in general, for Sartre, therefore has no objective. It is not the project of altering the ethnic landscape. Neither is it the project of changing the human condition, as if that were possible. It is simply the project of continually denying the human condition (see ASJ: part I, esp. pp. 50-4).

This example also illustrates the second important difference between Sartre's conception of a project and our ordinary notion: although Sartre describes projects as chosen, this does not mean that the person undertaking that project will necessarily believe or recognise that they are doing so. Sartre does not for a moment deny that the anti-Semites he describes really believe that there is a

(C) The Author 2006. Journal compilation (C) Blackwell Publishing Ltd. 2006 
Jewish conspiracy. He even emphasises that they are genuinely viscerally disgusted by the presence of Jewish people. His claim is just that they think and feel in this way because of their project of denying the human condition. His discussion of people suffering an inferiority complex provides another illuminating example of this aspect of his notion of a project. Such people, he claims, have undertaken the project of feeling inferior to others. This project involves formulating goals, failing to pursue them properly, failing thereby to achieve them, and taking this latter failure as evidence of inability. So this project dare not speak its name, for acknowledging that one has undertaken this project means acknowledging that the evidence one finds of one's inferiority is evidence one has fabricated oneself. For the same reason, one cannot be pleased by the achievement of convincing oneself of one's inferiority (see BEN: 493-7).

The broadly Sartrean theory of character, therefore, is that traits consist in projects undertaken in response to condition and circumstances, where such projects need not be construed as having the objective of bringing about some change in the world, and those engaged in such projects need not recognise that they are so engaged if their projects are described to them. Within Sartre's larger philosophy, this last point rests on his distinction between one's pre-reflective awareness of one's mental states, and one's reflective knowledge of them. We are always in some sense aware of what we are doing, for Sartre, so it is not strictly true to say that he considers anti-Semites to be unaware of the deep reason for their anti-Semitism. But such awareness does not amount to knowledge: one can be aware of something in this way without acknowledging that thing to oneself, without formulating beliefs about it, and without being able to report it. The acceptability of Sartre's conception of character, however, is independent of the acceptability of this theory of self-consciousness or the related theory of bad faith. One could happily accept that character consists in projects in the sense outlined here whilst also holding that people might be entirely unaware of these projects.

Situating Sartre within this broadly Sartrean position would involve answering further questions about his understanding of projects. Two questions central to this task concern the scope of influence had by one's projects. One of these concerns whether, in Sartre's opinion, all of one's actions manifest one's projects. He does seem to think that this is the case. His discussion of the relation between actions and the projects they manifest includes such phrases as the meanings implied by an act ... by every act' (BEN: 479) and 'every action, no matter how trivial' ( $B \mathcal{E} N$ : 481), and he claims that 'every human reaction is a priori comprehensible' ( $B \mathcal{E} N$ : 482). More precisely, he seems to hold that each action can be described in at least one way that makes clear the manifestation of some project or other: whether I sit down by the side of the road, or walk another hundred paces to the inn that I can see, my action can be described as relieving my fatigue, and for Sartre this act of relieving my fatigue although my fellow hikers do not do so manifests my character (see BEN: 492).

Morris (1976: 125) has argued that this reading is incompatible with Sartre's commitment to the idea that people can act out of character, but this seems to misunderstand what Sartre means by this: he means not that some actions do not

(C) The Author 2006. Journal compilation (C) Blackwell Publishing Ltd. 2006 
manifest projects, but that an action that does not fit the pattern of one's previous behaviour is 'a radical conversion' to a new way of living, 'an abrupt metamorphosis' of one's projects (BEN: 486; see also pp. 497-8). But of course one need not agree with Sartre on this in order to hold a broadly Sartrean view of the nature of character: one need only agree that one's characteristic actions result from one's projects.

The second question concerns whether Sartre holds character to consist ultimately in a single basic project, or in an integrated plurality of projects. He diagnoses Baudelaire as pursuing the aim of being unique, as we have seen, but it does not follow from this that he considers every action Baudelaire ever performed to manifest this project. And if he does think this of Baudelaire, it does not follow that he thinks that every individual can be so succinctly described. His discussion of the most basic description of character in Being and Nothingness, moreover, vacillates between terms such as 'original', 'global', or 'fundamental' 'choice' or 'project', on the one hand, and such pluralistic terms as the 'ensemble' or 'integration' of projects, on the other. ${ }^{15}$ Deciding whether or not Sartre held a settled view on this issue, and if so which one, might have important implications for understanding other aspects of his work on character, but for present purposes it does not matter either way. There is space within the broadly Sartrean position outlined in this paper for both the view that character ultimately consists in one basic project and the view that it consists in a set of projects.

The broadly Sartrean view of character, then, is that one's behaviour responds to the invitations and demands that the world seems to present, but that these invitations and demands are themselves determined by one's projects. Those who hold this view might differ over the nature and extent of one's awareness of one's projects, the scope of the influence had by those projects, and whether there are restrictions on the kinds of projects that can play this role. They can also disagree on whether human action can be described as free, and over what such a description means. In his early works, of course, Sartre considers action to be free in a sense that requires the falsehood of all forms of psychological determinism. His defence of this claim against the charge that the behaviour would be random if it were not determined relies on his theory that action manifests character traits that themselves manifest projects (BEN: 474-86). This latter claim, however, does not in itself imply his view of freedom: one could be a thoroughgoing determinist and still hold the broadly Sartrean view of character outlined in this paper, simply by claiming that projects determine behaviour and are themselves determined.

\section{VII}

This analysis of Sartre's account of character has various implications for understanding other areas of his philosophy. His theories of bad faith and the look in Being and Nothingness, for example, cannot be understood to claim that we

(C) The Author 2006. Journal compilation () Blackwell Publishing Ltd. 2006 
attribute character traits where there are none. They must rather claim that we attribute deterministic character traits where there are only non-deterministic ones, natures where there are essences.

It may further help to explain why Sartre often sounds as though he considers our misunderstanding of other people to be inevitable, while occasional comments indicate that he thinks we can escape it by a 'radical conversion' to 'an ethics of deliverance and salvation' (BEN: $434 \mathrm{n} 13)$ : if bad faith is understood as a project in the sense outlined above, then understanding people as having deterministic natures might be deeply rooted in our worldviews because it is rooted in our projects, particularly in the purportedly widespread project of bad faith. The abandonment of such attitudes towards others would thus require abandonment of the deeply held project of denying the reality of our own condition.

If this is the right way to understand the theories of bad faith and the look in Sartre's early works, then it would take exegetical work to show this to be the case. But it does seem that the foregoing analysis of projects opens this up as a promising way of making sense of Sartre's early theories of our misunderstandings of ourselves and of one another, with ramifications for our understanding of Sartre's early philosophy generally. Such exegetical work may also yield theories that are of general interest to debates over the epistemology of character.

The direct significance of the foregoing analysis is not, however, limited to understanding Sartre's work, even with the proviso that such understanding may be of interest to the epistemology of character. The Sartrean theory of character outlined above provides a new set of positions in the debate over character, a debate that bears directly on morality for those thinkers who hold that practical ethics should be concerned with the formation and development of character traits. Such thinkers include those who agree with Aristotle that the moral value of an action depends on whether it manifests a virtuous trait. But one need not agree with this in order to think that character formation and development should be central to our practical ethical concerns: one might think, for example, that the moral value of an action is a matter of its consequences, and that we should aim to develop character traits that incline us towards actions that on the whole have good consequences; or one might think that the moral value of an action is dependent on its motivation, and that we should try to develop character traits that incline us towards actions manifesting the right motives (see Nussbaum 1999: esp. § I; Trianosky 1997: esp. § 3). Whether one is Aristotelian, consequentialist, or Kantian with respect to the moral assessment of action, that is, one might agree that we should develop morally good characters, and if one agrees with this then the question of the nature of character should be central to one's concerns.

The Sartrean conception of character concurs with the Aristotelian view that is most commonly employed in philosophical theories of virtue on the issue of just how character traits dispose one to action. The two conceptions agree that one's character traits determine how important particular considerations are in the motivation of behaviour. They agree that when one deliberates one discerns the

(C) The Author 2006. Journal compilation (C) Blackwell Publishing Ltd. 2006 
relevant considerations and weighs up the relative importance of each, and that the weights assigned to each consideration are set by one's character traits: 'When I deliberate, the chips are down' (BEN: 473). They also agree that when one acts without conscious deliberation, this involves a kind of 'perception' of what to do, which depends on how heavily each noticed consideration weighs with one. In Sartre's terminology, one's traits determine the nature of one's situation, the invitations and demands with which the world presents one, the motifs of one's actions. ${ }^{16}$ One need not act according to one's deliberation or perception, of course, since these only incline one to behave in certain ways, but when one does so one's acts are in character.

The Sartrean and Aristotelian conceptions differ over just why one's deliberations and perceptions recommend the behaviour that they recommend. On both pictures, the relative weights accorded to each consideration result from one's relatively long-term emotional and desiderative states. Cowardly action might be recommended if one's attachment to safety is stronger than one's desire for honour, for example. But they differ over the origins of these states. On the Aristotelian picture, they result from habituation, so if one has never tasted honour, then one may well have developed more of an attachment to safety than to honour. Character development thus involves a process of coming to find certain things desirable that one did not previously desire. Rational persuasion that certain things are rightly desirable can only be part of this process. It is also necessary to practice the right kinds of behaviour, so that one can experience the pleasures particular to those kinds of behaviour, and so develop an attachment to them. ${ }^{17}$

On the Sartrean picture, on the other hand, the emotional and desiderative states that explain why one's deliberations and perceptions recommend certain courses of behaviour are in turn explained by one's projects. If this picture is right, then the aim of moral education is not, as it is on the Aristotelian picture, simply to persuade one that certain types of behaviour are desirable and to encourage one to experience the satisfaction of performing such behaviour. For the desirable behaviour may well be incompatible with one or more of one's projects, and if this is so then one cannot adopt it without a change in those projects. Moral education must therefore also aim to encourage the kinds of projects that can lead to morally good behaviour, however that is conceived, and discourage those that lead only or usually to bad behaviour. Attempts at moral self-improvement must similarly involve discovering which projects one's less admirable behaviour results from and considering whether one needs to abandon such projects, along with considering which kinds of projects would lead to better behaviour and attempting to adopt them.

If one agrees with Sartre that one's basic projects are so deeply held that a form of psychoanalysis is required in order to bring them to light, then such processes of self-improvement will be very difficult tasks. One can hold a broadly Sartrean theory of character, of course, without agreeing with Sartre on this point. But even if one does agree with him here, the difficult processes of moral education and self-improvement will not be impossible. Altering one's character in the

(C) The Author 2006. Journal compilation (C) Blackwell Publishing Ltd. 2006 
ways recommended by the Aristotelian view will be impossible, on the other hand, if the desirable traits in question are incompatible with one's projects and these are left untouched by persuasion and practice.

This opposition between the Sartrean and Aristotelian accounts of the roots of character raises the question of whether a single, monolithic account of the nature of character traits is required at all. Perhaps the right way to think about character will turn out to be some hybrid of Sartrean and Aristotelian theories. There are two ways in which the theories might combine. It might be that the Sartrean picture is right about some traits, the Aristotelian picture right about some others: perhaps some traits are rooted in projects, while others are not, and perhaps some of these others are the result of education and can be revised. Or it might be that at least some traits are partly rooted in one's projects and partly in one's experience, so that a change in either of these can alter such traits without a change in the other. Neither of these hybrids is ruled out by anything that has been said in this paper, though of course further investigation might show either to be impossible. Such investigation might equally show the right theory of character to be neither purely Aristotelian nor purely Sartrean, but to include insights from both accounts.

Jonathan Webber

Department of Philosophy

University of Sheffield

Sheffield

S10 $2 T N$

UK

j.m.webber@sheffield.ac.uk

\section{NOTES}

${ }^{1}$ Sartre raises the problem on p. 474 of Being and Nothingness, and provides his solution on p. 486, providing groundwork for this solution in the intervening pages.

${ }^{2}$ See especially the 1969 interview 'Itinerary of a Thought', particularly his assertion: 'I concluded that in any circumstances, there is always a possible choice. Which is false' (IT: $44)$.

${ }^{3}$ Recent philosophical publications that might seem to deny the existence of character traits, such as Gilbert Harman's paper 'The Nonexistence of Character Traits' (see also his 1999) and John Doris's book Lack of Character, do not actually expound such an extreme and implausible view. Behind their hyperbole, Harman is proposing that we abandon the language of character because it is misleading and of little use, and Doris is proposing that we understand character traits as being far more numerous and restricted in behavioural application than has generally been thought, so that while there is no such trait as sociability there might be such traits as sociability-at-parties, or sociability-towardscolleagues. Doris argues that if this is right, we should shift ethical attention from character-development to situation-management, but Peter Goldie (2004: chs. 3, 4) argues that it provides a novel framework for understanding character-development. Discussion

(C) The Author 2006. Journal compilation (C) Blackwell Publishing Ltd. 2006 
of these thoughts would take us outside the scope of this paper, but on Doris and Goldie see my papers 'Virtue, Character, and Situation' and 'Character, Global and Local', and on Harman my 'Character, Common-Sense, and Expertise'.

${ }^{4}$ See for example in passage quoted in note 2 above: IT: $43-5$.

5 See particularly Being and Nothingness, part 1, chapter 2 ('Bad Faith'); part 3, ch. 1, § IV ('The Look'); and part 3, ch. 3 ('Concrete Relations with Others').

6 This distinction between two senses of 'transcendence' in Sartre's philosophy is all that is needed for the present discussion. For a more sophisticated treatment, see Morris 1985 , § I.

${ }^{7}$ McCulloch also discusses the relation between Sartre's doctrines of freedom and of the lack of a nature on p. 43 , but this discussion is ambiguous in the same ways as that on pp. 56-64.

${ }^{8}$ Joseph Catalano (1976: 82-4) gives a similar account of Sartre's notion of facticity. Phyllis Sutton Morris (1976: ch. 4) holds that 'the pattern of past actions' amount to one's character in Sartre's system, but in the terms of this paper this is just a variant of the claim that Sartre's system has no place for character: if character traits are defined functionally as relatively stable dispositions to think, feel, and behave in certain ways in certain situations, then the pattern of past actions cannot itself play this role; and Morris does not claim that Sartre considers one's past actions, or indeed anything else, to play such a role.

9 Anthony Manser (1996: 60-1) gives a similar account of this example.

${ }^{10}$ Sartre's introduction to Being and Nothingness aims to establish this point, and he considers it fundamental to understanding our metaphysical relation to the world, which is why he reiterates it in various ways at pp. 220, 240, 351, and elsewhere.

${ }^{11}$ Morris (1985: 184, 186-7), also argues that the coherence of an individual's behaviour over time is left unexplained in The Transcendence of the Ego, and that the theory of the ego is revised in Being and Nothingness in order to account for it, though she does not notice that this revision involves rejection of the earlier claim that the ego does not really have qualities.

12 It is therefore misleading for Hazel Barnes to have used 'motive' to translate 'mobile' and 'cause' to translate 'motif' (see her footnote at BEN: 457). The English term 'motive' can be used to indicate either of these things (as can 'motivation'), and the term 'cause' might be taken to imply that the behaviour is a straightforward effect of the situation rather than a chosen response to it. Arlette Elkaïm-Sartre's revision of this translation adds the French terms in parentheses at a key point ( $B \mathcal{E} N: 467)$, but this may not be enough to prevent misunderstanding. Since the problem arises because there is no straightforward way of preserving the distinction in idiomatic English, I have retained the French terms.

13 This idea is central to Sartre's existentialist philosophical anthropology: in addition to the passages cited in the main text, see for example BEN : 48, 162, 219-224, 316, 345-6, 525-30, 637-8; see also STE: part III.

14 Although the idea that character is real and is a matter of projects is, as we have seen, absent from The Transcendence of the Ego, it first appears in Sartre's writings not in Being and Nothingness, but three years earlier in The Imaginary where 'the me' is defined as 'an harmonious synthesis of enterprises in the external world' (IPPI: 154).

15 The former phrases occur liberally throughout part 4, ch. 1, § I ('Freedom: The First Condition of Action'), and elsewhere. The latter occur on pp. 459 and 483, and elsewhere. The quotation from The Imaginary in note 14 above also seems to concur with the latter terms. This point about Sartre's apparent inconsistency is owed to Morris (1976: 118-120).

(C) The Author 2006. Journal compilation (C) Blackwell Publishing Ltd. 2006 
16 On deliberation, see for example: Sorabji 1980: 205-7; Wiggins 1980: 231-7; Williams 1981: 104. Sorabji and Wiggins provide a good guide to Aristotle's lengthy and scattered discussions of deliberation. On perception, see for example: Murdoch 1967: 20; McDowell 1979: § 2; Nussbaum 1990: 74, 79. Murdoch, McDowell, and Nussbaum are here quietly influenced by Aristotle's remarks at NE: 1143b11-14, 1109b18-23, 1126b2-4, 1142a27-30.

17 See: Aristotle NE: II.1-2 (1103a14-1104b3); Burnyeat 1980: throughout; Sorabji 1980: 214-8; Sherman 1989: ch. 5.

\section{REFERENCES}

Aristotle (NE) (2002), Nicomachean Ethics, translated by Christopher Rowe, with introduction and commentary by Sarah Broadie. Oxford: Oxford University Press.

Barnes, Hazel (1992), 'Sartre's Ontology: The Revealing and Making of Being', in Christina Howells (ed.), The Cambridge Companion to Sartre. Cambridge: Cambridge University Press.

Burnyeat, M. F. (1980), 'Aristotle on Learning to be Good', in Amélie Oksenberg Rorty, Essays on Aristotle's Ethics. Berkeley: University of California Press.

Catalano, Joseph S. (1976), A Commentary on Jean-Paul Sartre's Being and Nothingness. Chicago: University of Chicago Press.

Caws, Peter (1979), Sartre. London: Routledge and Kegan Paul, The Arguments of the Philosophers.

Doris, John (2002), Lack of Character: Personality and Moral Behaviour. Cambridge: Cambridge University Press.

Goldie, Peter (2004), On Personality. London: Routledge.

Harman, Gilbert (1999), 'Moral Philosophy Meets Social Psychology: Virtue Ethics and the Fundamental Attribution Error,' Proceedings of the Aristotelian Society, 99,3: 315-331.

(2000), 'The Nonexistence of Character Traits', Proceedings of the Aristotelian Society, 100,2: 223-226.

Howells, Christina (1992), 'Conclusion: Sartre and the Deconstruction of the Subject', in Christina Howells (ed.), The Cambridge Companion to Sartre. Cambridge: Cambridge University Press.

Husserl, Edmund (1950), Cartesian Meditations, translated by Dorion Cairns, The Hague: Martinus Nijhoff.

McCulloch, Gregory (1994), Using Sartre: An Analytical Introduction to Early Sartrean Themes. London and New York: Routledge.

McDowell, John (1979), 'Virtue and Reason', Monist, 62: 331-350.

Manser, Anthony (1966), Sartre: A Philosophic Study. New York: Oxford University Press.

Morris, Phyllis Sutton (1976), Sartre's Concept of a Person: An Analytic Approach. Amherst: University of Massachusetts Press.

- (1985), 'Sartre on the Transcendence of the Ego', Philosophy and Phenomenological Research, 46,2: 179-198.

Murdoch, Iris (1967), The Sovereignty of Good Over Other Concepts. Cambridge: Cambridge University Press.

Nussbaum, Martha C. (1990), 'The Discernment of Perception: An Aristotelian Conception of Private and Public Rationality', in Love's Knowledge: Essays on Philosophy and Literature. Oxford: Oxford University Press.

_ (1999), 'Virtue Ethics: A Misleading Category?', Journal of Ethics, 3: 163-201.

\footnotetext{
(C) The Author 2006. Journal compilation (C) Blackwell Publishing Ltd. 2006
} 
Richmond, Sarah (2004), 'Introduction', in Sartre Jean-Paul, The Transcendence of the Ego: A Sketch for a Phenomenological Description, translated by Andrew Brown. London and New York: Routledge.

Sartre, Jean-Paul (TE) (2004), The Transcendence of the Ego: A Sketch for a Phenomenological Description, translated by Andrew Brown. London and New York: Routledge, First published as 'La Transcendance de l'Ego: Esquisse d'une description phénomenologique', Recherches Philosophiques, 6 (1936-7): 8-123.

Sartre, Jean Paul (STE) (1962), Sketch for a Theory of the Emotions, translated by Philip Mairet London: Methuen. First published as Esquisse d'une Théorie des Émotions (Paris: Hermann, 1939).

Sartre, Jean-Paul (IPPI) (2003), The Imaginary: A Phenomenological Psychology of the Imagination, translated by Jonathan Webber. London and New York: Routledge, First published as L'Imaginaire: Psychologie Phénoménologique de l'Imagination (Paris: Gallimard, 1940).

- $(B \mathcal{E} N)$ (2003), Being and Nothingness: An Essay in Phenomenological Ontology, translated by Hazel E. Barnes, with corrections by Arlette Elkaïm-Sartre. London: Routledge Classics. First published as L'Être et le Néant: Essai d'Ontologie Phénoménologique (Paris: Gallimard, 1943).

$(E \mathcal{E H})(1948)$, Existentialism and Humanism, translated by Philip Mairet. London: Methuen. First published as L'Existentialisme est un Humanisme (Paris: Nagel, 1946). - (ASJ) (1948), Anti-Semite and Jew, translated by George J. Becker. New York: Schocken Books. First published as Réflexions sur la Question Juive (Paris: Morihien, 1946).

(B) (1950), Baudelaire, translated by Martin Turnell. New York: New Directions. First published as Baudelaire (Paris: Gallimard, 1946).

- (IT) (1996), 'Itinerary of a Thought', interview in New Left Review, I/58(NovemberDecember): 43-66.

Sherman, Nancy (1989), The Fabric of Character: Aristotle's Theory of Virtue. Oxford: Clarendon.

Sorabji, Richard (1980), 'Aristotle on the Role of Intellect in Virtue', in Oksenberg Amélie Rorty (ed.), Essays on Aristotle's Ethics. Berkeley: University of California Press. Reprinted from Proceedings of the Aristotelian Society, 74, 2 (1974): 107-129.

Trianosky, Gregory Velazco y (1997), 'What Is Virtue Ethics All About?', in Daniel Statman. Virtue Ethics: A Critical Reader. Edinburgh: Edinburgh University Press.

Webber, Jonathan (2006), 'Virtue, Character and Situation', Journal of Moral Philosophy, 3,2.

- (forthcoming), 'Character, Global and Local', Utilitas.

- (forthcoming), 'Character, Common-Sense, and Expertise'.

Wiggins, David (1980), 'Deliberation and Practical Reason', in Amélie Oksenberg Rorty (ed.), Essays on Aristotle's Ethics. Berkeley: University of California Press.

(C) The Author 2006. Journal compilation () Blackwell Publishing Ltd. 2006 